\title{
In Vitro Antimicrobial Activity of Spices and Medicinal Herbs against Selected Microbes Associated with Juices
}

\author{
Romika Dhiman, ${ }^{1}$ Neeraj Aggarwal, ${ }^{1}$ Kamal Rai Aneja, ${ }^{2}$ and Manpreet Kaur ${ }^{1}$ \\ ${ }^{1}$ Department of Microbiology, Kurukshetra University, Kurukshetra, India \\ ${ }^{2}$ Vaidyanath Research, Training and Diagnostic Centre, Kurukshetra, India \\ Correspondence should be addressed to Romika Dhiman; romikadhiman@gmail.com
}

Received 18 September 2015; Revised 12 November 2015; Accepted 15 November 2015

Academic Editor: Joseph Falkinham

Copyright (c) 2016 Romika Dhiman et al. This is an open access article distributed under the Creative Commons Attribution License, which permits unrestricted use, distribution, and reproduction in any medium, provided the original work is properly cited.

In the present investigation, comparison of antimicrobial activities of different spices, Curcuma longa, Zingiber officinale, and Mentha arvensis, and medicinal herbs, such as Withania somnifera, Rauvolfia serpentina, Emblica officinalis, Terminalia arjuna, and Centella asiatica, was evaluated. Different extraction solvents (acetone, methanol, ethanol, and water) were used and extracts were examined against Bacillus cereus, Serratia sp., Rhodotorula mucilaginosa, Aspergillus flavus, and Penicillium citrinum isolated from juices. Extracts from the medicinal herb and spices have significant activity. B. cereus was the most sensitive and $R$. mucilaginosa was the most resistant among the microorganisms tested. Ethanolic and methanolic extract of C. asiatica displayed maximum diameter of inhibition zone against bacteria and yeast and percentage mycelial inhibition against moulds. This study confirmed the potential of selected extracts of spices as effective natural food preservative in juices.

\section{Introduction}

Emergence of new technologies in food preservation leads to a reduction in the levels of preservatives and promotes the use of "naturally derived antimicrobials of animal, plants, and microbial origin [1]. Antimicrobial compounds derived from plants were used for centuries in food preservation. Egyptians, Chinese, and Indians used spices and essential oils since ancient time. Some of the spices such as mint, garlic, and ginger are still practiced in alternative health remedies in India [2, 3]. About 250 to 500 thousand plant species are estimated to exist on the planet and only between 1 and $10 \%$ of them are used as food by humans and other animals [4]. Spices and herbs used in foods as flavoring agents, in addition to enhancing flavors, were used as folk medicines and food preservatives. Spices and herbs extend the shelf life of foods by restricting rancidity through their antioxidant activity or through their bacteriostatic and bactericidal activity [5].

Spices, herbs, and their constituents are generally recogonised as safe (GRAS) and approved by several regulatory agencies such as US Food and Drug Act, the European Union standards, Codex Alimentarius, and Food Safety and
Standards Authority of India [3]. In India, the trend of consumption of spices and herbs in food or using them as medicine aims to maintain proper sanitation, health, and hygiene and to increase longevity of life. Several spices such as ajowan, clove, ginger, black pepper, cumin, and asafetida are commonly used in the Indian diet $[3,6,7]$. Literature cited the work of several authors on the antimicrobial activity of plants against wide range of bacteria, yeasts, and moulds [2, 3, 820]. The general description of spices and herbs used in the present study is tabulated in Table 1 .

Spices and herbs, owing to their natural origin, attract more attention of consumers that have doubt regarding the safety of chemical preservatives. Several plant extracts have gained momentum in recent years due to their bioactive principals and formed the basis of pharmaceutical and food processing industries [17, 21].

Unpasteurized fruit juice consumption has increased in the last decades, which is attributed to the contents of antioxidants, vitamins, and minerals. Fresh fruit juices are highly vulnerable to spoilage, since fluid components are in contact with air and microorganisms form the environment while handling [22]. Fruit juices spoilage bacteria include acid 


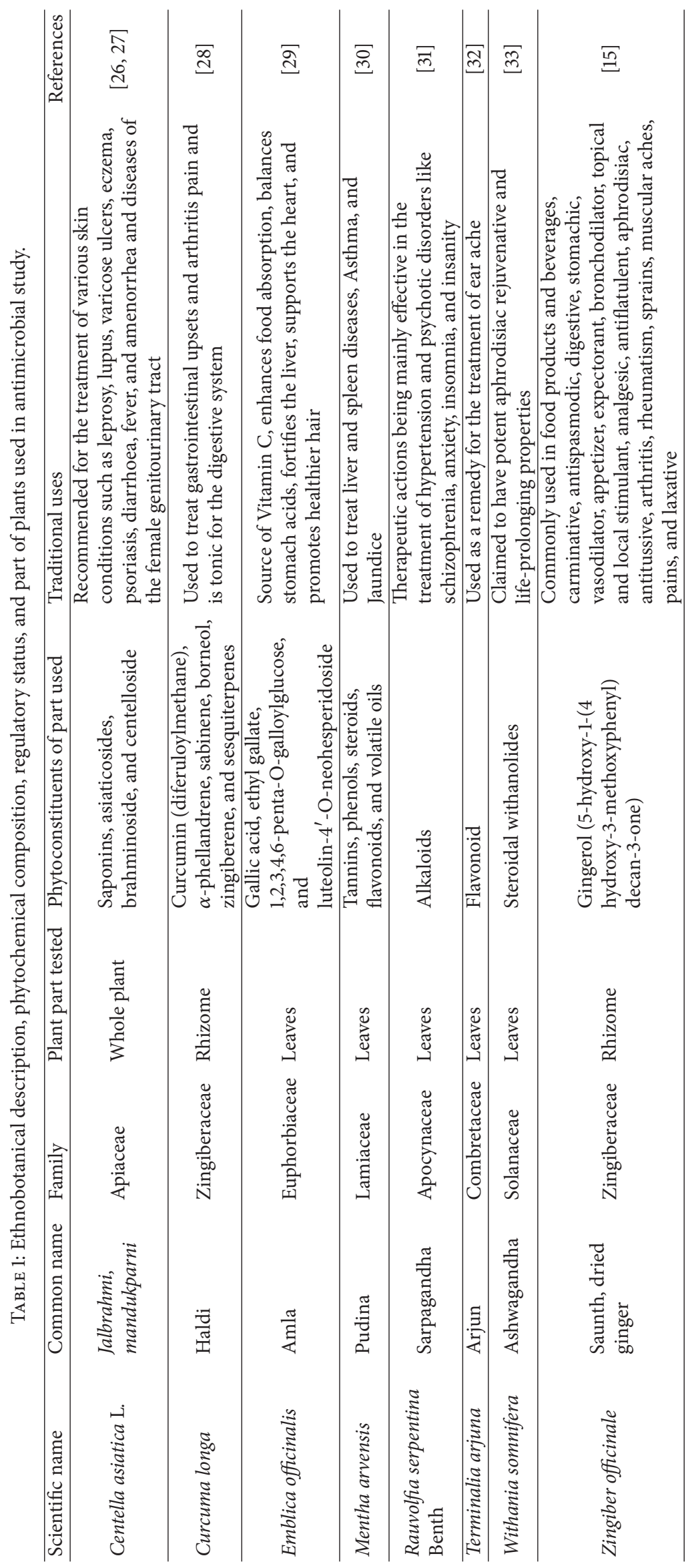


tolerant bacteria such as acetic acid bacteria, lactic acid bacteria, Clostridium, Bacillus, members of Enterobacteriaceae family (Klebsiella sp., Citrobacter sp., and Serratia sp.), and some heat resistant bacteria such as Alicyclobacillus acidoterrestris and Propionibacterium cyclohexinicum. Among yeasts, Pichia, Candida, Saccharomyces, and Rhodotorula are commonly encountered genera responsible for spoilage of juices. Certain common moulds such as Penicillium sp., Aspergillus sp., Eurotium, Alternaria, Cladosporium, Paecilomyces, and Botrytis have also been reported in spoilage of fruit juices. The presence of pathogenic bacteria and mycotoxin producing mould cannot be ruled out in fruit juice which has been responsible for the increase in food borne outbreaks with the consumption of fresh fruit juices during the last two decades $[14,23,24]$.

Therefore, the main objective of this study was to examine the in vitro antimicrobial activity of different spices and herbs extracts and to compare the effect of different solvents in the extraction method for antimicrobial activity.

\section{Materials and Methods}

2.1. Plant Materials. Three Indian spices, pudina, saunth, and haldi, were procured from local market in Yamunanagar, Haryana, India. Four medicinal plants herbs, amla, brahmi, ashwgandha, arjun, and sarpagandha were collected from Ch. Devi Lal Park at Khizrabad, Yamunanagar, Haryana, India. The taxonomic identity of these plants was confirmed by Dr. B. D. Vashishta, plant taxonomist, professor in the Department of Botany, Kurukshetra University, Kurukshetra. The scientific name and tested parts of the 8 plants are detailed in Table 1.

2.2. Extraction of Plant Material. Four different solvents, namely, ethanol, methanol, acetone, and aqueous (hot and cold), were used for extraction and plant extracts were prepared according to the methods described by Sharma et al. [25].

2.3. Test Microorganisms. In the previous study [24], microbiological analysis of fruit juices was done by serial dilution agar plate technique. On the basis of percentage of occurrence of microorganisms in juice samples, one Gram-positive bacterium, one Gram-negative bacterium, one yeast, and two moulds were selected for examining the antimicrobial activity of spices. Bacterial strains were identified on the basis of gram staining and biochemical and molecular characteristics (16S rRNA sequencing) [23]. Yeast was identified on the basis of staining, morphological, cultural characteristics, and molecular characteristics (28S rRNA sequencing). Moulds were identified on the basis of morphological and cultural characteristics and further identification was confirmed by CABI International Mycological Institute, UK.

Two bacteria, namely, Serratia $\left(\right.$ KC67407 ${ }^{*}$ ) and Bacillus cereus $\mathrm{KRCl}$ (KC67408), one yeast, Rhodotorula mucilaginosa (KC67409), and two moulds, Aspergillus flavus (504472**) and Penicillium citrinum (504473), were identified. The bacterial isolates were subcultured on nutrient agar and $R$. mucilaginosa, A. flavus, and P. citrinum were subcultured on potato dextrose agar and incubated aerobically at $37^{\circ} \mathrm{C}$ and $25^{\circ} \mathrm{C}$, respectively. The media were procured from Hi Media Laboratory Pvt. Ltd., Bombay, India ( ${ }^{*}$ nucleotide sequence of all microorganisms has been submitted to GenBank database which provided the GenBank accession number, KC67407KC67409; ${ }^{* *}$ International Mycological Institute reference number).

\subsection{Screening for Antimicrobial Activity against Bacteria and} Yeast. The acetone, methanol, ethanol, and hot and cold aqueous extracts of different plants were used for evaluation of antimicrobial activity by the agar well diffusion method. In this method, a pure isolate of bacteria and yeast was grown on NA and PDA plates and incubated at $37^{\circ} \mathrm{C}$ and $25^{\circ} \mathrm{C}$ for $24 \mathrm{~h}$ and $72 \mathrm{~h}$, respectively. One plate of each microorganism was taken and colonies were transferred into normal saline $(0.85 \%)$ under aseptic conditions. Density of each microbial suspension was adjusted to be equal to that of $10^{6} \mathrm{cfu} / \mathrm{mL}$ (standardized by $0.5 \mathrm{McF}$ arland standard) and to be used as the inoculum for performing an agar well diffusion assay. $100 \mu \mathrm{L}$ of the inoculum of each test organism was spread onto the agar plates so as to achieve a confluent growth. The agar plates were allowed to dry and $8 \mathrm{~mm}$ wells were made with a sterile borer in the inoculated agar plates. The lower portion of each well was sealed with molten agar medium. The dried extracts were reconstituted to $20 \%$ in dimethyl sulfoxide (DMSO) to the final concentration of $100 \mathrm{mg} / \mathrm{mL}$ for the bioassay analysis. A $100 \mu \mathrm{L}$ volume of each extract was propelled directly into the wells (in triplicate) of the inoculated agar plates for each test organism. The plates were allowed to stand for $1 \mathrm{~h}$ at room temperature $\left(40^{\circ} \mathrm{C}\right)$ for diffusion of the extract into agar and incubated at $37^{\circ} \mathrm{C}$ and $25^{\circ} \mathrm{C}$ for $24 \mathrm{~h}$ and $72 \mathrm{~h}$, respectively. Sodium benzoate $(100 \mathrm{mg} / \mathrm{mL})$ was used as positive reference standards to determine the sensitivity of each microbial species tested. Sterile DMSO served as the negative control. The antimicrobial activity, indicated by an inhibition zone surrounding the well containing the extract, was recorded if the zone was greater than $8 \mathrm{~mm}$. The experiments were performed in triplicate and the mean values of the diameter of inhibition zones \pm standard deviations were calculated [34].

2.5. Screening for Antimicrobial Activity against Moulds. The antimould activity of plant extracts in different solvent was accessed by poison food technique. $100 \mu \mathrm{L}$ of plant extract with concentration of $100 \mathrm{mg} / \mathrm{mL}$ was poured into sterile Petri plate $(90 \mathrm{~mm}$ diameter) and $15 \mathrm{~mL}$ of molten potato dextrose agar (PDA) was added to the Petri plate and swirled to achieve a uniform mixture and allowed them to solidify at room temperature. The solidified agar plates were inoculated at the centre with fungal disc ( $6 \mathrm{~mm}$ diameter), obtained from the actively growing one-week-old colony of the test fungus, placed with inoculums side down in the centre of each Petri plate aseptically and incubated at point $25^{\circ} \mathrm{C}$ for 7 days. DMSO was used as negative control and chemical preservative sodium benzoate served as the positive control. The antifungal activity of each extract was evaluated by 
measuring the radial growth of fungus in terms of diameter and expressed as percentage mycelia inhibition determined by applying the following formula [35-37]:

$$
\text { inhibition of mycelia growth } \%=\frac{\left(d_{c}-d_{t}\right)}{d_{c}} \times 100,
$$

where $d_{c}$ is average diameter of fungal colony in negative control plates and $d_{t}$ is average diameter of fungal colony in extract added plates.

\subsection{Determination of Minimum Inhibitory Concentration.} Minimum inhibitory concentration (MIC) for each test organism was determined by the broth macrodilution method [38].

2.7. Statistical Analysis. The experimental results were repeated thrice in triplicate each time and expressed as mean $\pm \mathrm{SD}$ and results were statistically evaluated using SPSS software version 16 at 5\% significant level. Means were compared using Tukey's simultaneous test set at $p<0.05$.

\section{Results and Discussion}

3.1. Antimicrobial Activity of Plant Extracts. The dietary herb and spices are used as food additives in foods not only to improve the sensory characteristics of food but also to increase the shelf life by reducing or eliminating survival of pathogenic bacteria [2].

In the present study, the antimicrobial activity of the different plant extracts in different solvents was examined. Perusal data in Table 2 revealed the mean diameters of the inhibition zones of all plant extracts against two bacteria and yeast and percentage mycelia inhibition against two moulds. There was significant variation $(p<0.05)$ observed between acetone, methanol, ethanol, cold aqueous, and hot aqueous solvents for the antimicrobial activities of each of the tested plant extracts and microorganisms.

For B. cereus (KC67408), the DIZ values of 18 extracts (accounting for $45 \%$ of the 40 tested extracts) were between $19.6 \mathrm{~mm}$ and $29.3 \mathrm{~mm}$ and those of 16 extracts (40\%) were between $12.3 \mathrm{~mm}$ and $19.3 \mathrm{~mm}$. However, 6 extracts had no inhibitory activity. Ethanolic extract of C. asiatica exhibited the strongest antibacterial activity $(\mathrm{DIZ}=29.3 \mathrm{~mm})$, followed by methanolic extract $(\mathrm{DIZ}=26.3 \mathrm{~mm})$ and ethanolic extract of $R$. serpentina (DIZ $=25.3 \mathrm{~mm})$ (Table 2).

For Serratia (KC67407), a total of 25 extracts (62.5\%) exhibited inhibitory activity with DIZ values ranging from $11.3 \mathrm{~mm}$ to $22.6 \mathrm{~mm}$, and 47 extracts had low activity. The remaining 15 extracts had no inhibitory activity (Table 2 ). The sample with strongest antimicrobial activity was methanolic extract of $T$. arjuna (DIZ $=22.6 \mathrm{~mm}$ ), followed by acetonic extract of R. serpentina (21.3 mm).

For R. mucilaginosa (KC67409), the DIZ values of 9 extracts $(22.5 \%)$ ranged from $13.3 \mathrm{~mm}$ to $25.3 \mathrm{~mm}$ (Table 2). Thirty-one extracts (77.5\%) showed no inhibitory activity. Ethanolic extract of $C$. asiatica showed the strongest inhibitory activity (DIZ $=20.6 \mathrm{~mm})$, followed by methanolic extract of T. arjuna (19.3 mm).
Of the two moulds tested, for A. flavus, the percentage mycelial inhibition of 8 extracts (20\%) varied from $20.6 \mathrm{~mm}$ to $26.3 \mathrm{~mm}$. Nine extracts $(22.5 \%)$ had low inhibitory activity (percentage mycelial inhibition ranging between $11.6 \mathrm{~mm}$ and $19.3 \mathrm{~mm}$ ). The other 23 extracts (57.5\%) showed no inhibitory activity. Ethanolic extract of C. asiatica exhibited the strongest antimould activity (percentage mycelial inhibition $=26.3 \mathrm{~mm}$ ), followed by methanolic extract of $C$. asiatica and T. arjuna $(24.6 \mathrm{~mm})$. For $P$. citrinum, 8 extracts exhibited high inhibitory activity (percentage mycelial inhibition $=19.6 \mathrm{~mm}-24.3 \mathrm{~mm}$ ) and nine extracts possessed less inhibitory activity (percentage mycelial inhibition ranging between $10.3 \mathrm{~mm}$ and $19.3 \mathrm{~mm}$ ), while the other 23 extracts had no inhibitory activity. Methanolic extract of C. asiatica $(24.3 \mathrm{~mm})$ showed the strongest inhibitory activity, followed by ethanolic extract of $C$. asiatica and $W$. somnifera $(23.3 \mathrm{~mm})$.

Literature search revealed the in vitro and in vivo antimicrobial activities of plant extracts and essential oils against food borne pathogens but they are difficult to compare owing to the use of different methods of extraction, solvents, microbial strains, and antimicrobial test methods $[3,5,16$, 17, 39, 40]. In the present analysis, 4 plants, C. asiatica, E. officinalis, $M$. arvensis, and T. arjuna, exhibited broad spectrum activity against tested microbes. The present results were in line with the observation of earlier workers [5-7, 1517, 41, 42]. Methanolic and ethanolic extract of C. asiatica exhibited maximum zone of inhibition against all tested microorganisms in the present investigation. The antimicrobial potential of $C$. asiatica was observed by Arumugam et al. [43] in a study to check the antimicrobial efficacy of C. asiatica against B. cereus, S. aureus, and Pseudomonas aeruginosa in four different solvents such as methanol, chloroform, water, and acetone and they found that methanolic extract of C. asiatica leaves at the concentration of $50 \mu \mathrm{g}$ per $\mathrm{mL}$ displayed activity (24-27 mm) against all tested microorganisms. The antimicrobial efficacy of $C$. asiatica is due to the presence of terpenoids [44]. Acetonic extracts of T. arjuna displayed maximum zone of inhibition $(16-28 \mathrm{~mm})$ against $S$. aureus, Acinetobacter, P. aeruginosa, and Proteus mirabilis in comparison to the other extracts (methanolic, ethanolic, and water extracts); however, all the extracts lacked activity against Candida albicans [32]. In the present investigation, methanolic and ethanolic extracts of T. arjuna exhibited antimicrobial activity against all tested microbes due to the presence of flavonoids (luteolin) $[45,46]$.

Ethanolic extract of E. officinalis leaves showed more activity against $P$. aeruginosa, Proteus mirabilis, $S$. aureus, and $B$. cereus in comparison to ethanolic extract of $M$. arvensis leaves at the concentration of $100 \mathrm{mg} / \mathrm{mL}$ [47]. However, in the present investigation, the ethanolic extracts of $M$. arvensis displayed more activity in comparison to E. officinalis ethanolic extract at the concentration of $100 \mathrm{mg} / \mathrm{mL}$. The antimicrobial potential of E. officinalis and M. arvensis is attributed to the presence of hydrolysable tannins and menthol, respectively [48]. Although, in present investigation, $R$. serpentina and $W$. somnifera revealed antibacterial and antimould activity but lacked antiyeast activity, several 
TABLE 2: Antimicrobial activity of plant extracts in different solvents.

\begin{tabular}{|c|c|c|c|c|c|c|}
\hline \multirow{2}{*}{ Plant } & \multirow{2}{*}{ Solvent } & \multicolumn{3}{|c|}{ Diameter of inhibition zone } & \multicolumn{2}{|c|}{ Percentage mycelia inhibition } \\
\hline & & B. cereus & Serratia sp. & R. mucilaginosa & A. flavus & P. citrinum \\
\hline \multirow{5}{*}{ Centella asiatica } & Acetone & $23.3_{\mathrm{bx}}^{*} \pm 1.52^{* *}$ & - & - & - & - \\
\hline & Methanol & $27.3_{\mathrm{cx}} \pm 0.57$ & $15.3_{\text {cy }} \pm 0.57$ & $18.3_{\mathrm{cz}} \pm 0.57$ & $24.6_{\mathrm{bu}} \pm 0.57$ & $23.3_{\mathrm{bv}} \pm 1.52$ \\
\hline & Ethanol & $29.3_{\mathrm{dx}} \pm 0.57$ & $12.3_{\mathrm{dy}} \pm 1.52$ & $20.6_{\mathrm{dz}} \pm 0.57$ & $26.3_{\mathrm{cu}} \pm 1.52$ & $24.3_{\mathrm{cv}} \pm 0.57$ \\
\hline & Cold aqueous & - & - & - & - & - \\
\hline & Hot aqueous & - & - & - & - & - \\
\hline \multirow{5}{*}{ Curcuma longa } & Acetone & $22.3_{\mathrm{bx}} \pm 1.52$ & $13.3_{\text {by }} \pm 1.52$ & - & - & - \\
\hline & Methanol & $20.3_{\mathrm{cx}} \pm 1.52$ & - & - & - & - \\
\hline & Ethanol & $17.3_{\mathrm{dx}} \pm 1.52$ & - & - & - & - \\
\hline & Cold aqueous & - & - & - & - & - \\
\hline & Hot aqueous & - & - & - & - & - \\
\hline \multirow{5}{*}{ Emblica officinalis } & Acetone & $22.3_{b x} \pm 0.57$ & $19.3_{\text {by }} \pm 0.57$ & $18.6_{\mathrm{bz}} \pm 1.52$ & $19.3_{\mathrm{bu}} \pm 1.52$ & $20.6_{\mathrm{bv}} \pm 1.52$ \\
\hline & Methanol & $19.6_{\mathrm{cx}} \pm 1.52$ & $14.3_{\text {cy }} \pm 0.57$ & $16.3_{\mathrm{cz}} \pm 0.57$ & $17.6_{\mathrm{cu}} \pm 1.52$ & $18.3_{\mathrm{cv}} \pm 0.57$ \\
\hline & Ethanol & $17.3_{\mathrm{dx}} \pm 0.57$ & $15.3_{\mathrm{dy}} \pm 0.57$ & $14.3_{\mathrm{dz}} \pm 0.57$ & $12.6_{\mathrm{du}} \pm 0.57$ & $13.6_{\mathrm{dv}} \pm 0.57$ \\
\hline & Cold aqueous & $14.6_{\mathrm{ex}} \pm 0.57$ & - & - & - & - \\
\hline & Hot aqueous & $12.6_{\mathrm{fx}} \pm 0.57$ & - & - & - & - \\
\hline \multirow{5}{*}{ Mentha arvensis } & Acetone & $26.3_{\mathrm{bx}} \pm 0.57$ & $19.3_{\text {by }} \pm 1.52$ & - & $22.3_{\mathrm{bu}} \pm 0.57$ & $20.6_{\mathrm{bv}} \pm 0.57$ \\
\hline & Methanol & $23.3_{\mathrm{cx}} \pm 0.57$ & $14.3_{\text {cy }} \pm 0.57$ & - & $17.6_{\mathrm{cu}} \pm 1.52$ & $15.3_{\mathrm{cv}} \pm 1.52$ \\
\hline & Ethanol & $24.3_{\mathrm{dx}} \pm 0.57$ & $16.6_{d y} \pm 0.57$ & - & $16.6_{\mathrm{du}} \pm 1.52$ & $14.3_{\mathrm{dv}} \pm 0.57$ \\
\hline & Cold aqueous & $19.3_{\mathrm{ex}} \pm 0.57$ & $11.3_{\text {ey }} \pm 0.57$ & - & - & - \\
\hline & Hot aqueous & $15.6_{\mathrm{fx}} \pm 1.52$ & - & - & - & - \\
\hline \multirow{5}{*}{ Rauvolfia serpentina } & Acetone & $22.3_{\mathrm{bx}} \pm 0.57$ & $21.3_{\text {by }} \pm 1.52$ & - & $17.3_{\mathrm{bu}} \pm 1.52$ & $19.3_{\mathrm{bv}} \pm 1.52$ \\
\hline & Methanol & $26.6_{\mathrm{cx}} \pm 0.57$ & $18.6_{\text {cy }} \pm 0.57$ & - & $15.6_{\mathrm{cu}} \pm 1.52$ & $12.6_{\mathrm{cv}} \pm 1.52$ \\
\hline & Ethanol & $25.6_{\mathrm{dx}} \pm 1.52$ & $17.3_{\mathrm{dy}} \pm 0.57$ & - & - & - \\
\hline & Cold aqueous & $19.3_{\mathrm{ex}} \pm 0.57$ & $14.6_{\mathrm{ey}} \pm 1.52$ & - & - & - \\
\hline & Hot aqueous & $17.6_{\mathrm{fx}} \pm 0.57$ & $12.6_{\mathrm{fy}} \pm 0.57$ & - & - & - \\
\hline \multirow{5}{*}{ Terminalia arjuna } & Acetone & $19.3_{\mathrm{bx}} \pm 0.57$ & $18.6_{\text {by }} \pm 0.57$ & $17.6_{\mathrm{bz}} \pm 0.57$ & $20.6_{\text {bu }} \pm 1.52$ & $17.3_{\mathrm{bv}} \pm 0.57$ \\
\hline & Methanol & $24.6_{\mathrm{cx}} \pm 0.57$ & $22.6_{\mathrm{cy}} \pm 0.57$ & $19.3_{\mathrm{cz}} \pm 0.57$ & $24.6_{\mathrm{cu}} \pm 0.57$ & $21.3_{\mathrm{cv}} \pm 1.52$ \\
\hline & Ethanol & $21.3_{\mathrm{dx}} \pm 0.57$ & $19.3_{\mathrm{dy}} \pm 0.57$ & $16.6_{\mathrm{dz}} \pm 0.57$ & $21.6_{\mathrm{du}} \pm 1.52$ & $15.6_{\mathrm{dv}} \pm 0.57$ \\
\hline & Cold aqueous & $15.6_{\mathrm{ex}} \pm 0.57$ & $14.6_{\text {ey }} \pm 0.57$ & $13.3_{\mathrm{ez}} \pm 0.57$ & $11.6_{\mathrm{eu}} \pm 1.52$ & $10.3_{\mathrm{ev}} \pm 0.57$ \\
\hline & Hot aqueous & $12.3_{\mathrm{fx}} \pm 0.57$ & - & - & - & \\
\hline \multirow{5}{*}{ Withania somnifera } & Acetone & $20.3_{\mathrm{bx}} \pm 0.57$ & $18.6_{\text {by }} \pm 0.57$ & - & $18.3_{\mathrm{bu}} \pm 0.57$ & $19.6_{\mathrm{bv}} \pm 1.52$ \\
\hline & Methanol & $15.6_{\mathrm{cx}} \pm 1.52$ & $13.3_{\text {cy }} \pm 0.57$ & - & $20.6_{\mathrm{cu}} \pm 0.57$ & $22.3_{\mathrm{cv}} \pm 0.57$ \\
\hline & Ethanol & $14.3_{\mathrm{dx}} \pm 1.52$ & $12.3_{\mathrm{dy}} \pm 1.52$ & - & $22.6_{\mathrm{du}} \pm 1.52$ & $23.3_{\mathrm{dv}} \pm 0.57$ \\
\hline & Cold aqueous & - & - & - & - & - \\
\hline & Hot aqueous & - & - & - & - & - \\
\hline \multirow{5}{*}{ Zingiber officinale } & Acetone & $23.3_{\mathrm{bx}} \pm 0.57$ & $18.6_{\text {by }} \pm 0.57$ & - & - & - \\
\hline & Methanol & $21.3_{\mathrm{cx}} \pm 1.52$ & $13.6_{c y} \pm 0.57$ & - & - & - \\
\hline & Ethanol & $19.3_{\mathrm{dx}} \pm 0.57$ & $11.3_{\mathrm{dz}} \pm 0.57$ & - & - & - \\
\hline & Cold aqueous & $17.6_{\mathrm{ex}} \pm 0.57$ & - & - & - & - \\
\hline & Hot aqueous & $12.3_{\mathrm{fx}} \pm 0.57$ & - & - & - & - \\
\hline \multicolumn{2}{|c|}{ Sodium benzoate } & $20.6_{\mathrm{ax}} \pm 0.57$ & $16.6_{\mathrm{ay}} \pm 0.57$ & $14.6_{\mathrm{az}} \pm 0.57$ & $30.6 \pm 0.57$ & $26.3 \pm 0.57$ \\
\hline
\end{tabular}

${ }^{*}$ Values, including diameter of the well $(8 \mathrm{~mm})$, are means of three replicates. ${ }^{* *}$ Standard deviation within five extracts and control of the same spice with three different microorganisms tested different letters are significantly $(p<0.05)$ different. - : no activity.

authors confirmed antibacterial and antifungal potential of $W$. somnifera and R. serpentina $[31,33,49,50]$.

Sunilson et al. [15] observed the antimicrobial activity of C. longa and $Z$. officinalis in four different solvents (petroleum ether, chloroform, methanol, and water) against food borne pathogens. The solvent extracts of C. longa and Z. officinalis displayed antibacterial and antiyeast activity; however, in present investigation, C. longa and Z. officinalis possessed antibacterial activity.

The extraction of biologically active compound from plant material is largely dependent on the type of the solvent used in the extraction procedure. The present study revealed that the organic extracts provided more powerful antimicrobial activity compared to aqueous extracts. Among 
TABLE 3: MIC of plant extracts in different solvents.

\begin{tabular}{|c|c|c|c|c|c|c|}
\hline \multirow{2}{*}{ Plant } & \multirow{2}{*}{ Solvent } & \multicolumn{5}{|c|}{ MIC value of different plant extracts } \\
\hline & & B. cereus & Serratia sp. & R. mucilaginosa & A. flavus & P. citrinum \\
\hline \multirow{3}{*}{ Centella asiatica } & Acetone & 12.5 & $\mathrm{Nt}$ & $\mathrm{Nt}$ & $\mathrm{Nt}$ & $\mathrm{Nt}$ \\
\hline & Methanol & 6.25 & 25 & 25 & 12.5 & 12.5 \\
\hline & Ethanol & 3.12 & $\mathrm{Nt}$ & 12.5 & 6.25 & 12.5 \\
\hline \multirow{3}{*}{ Curcuma longa } & Acetone & 12.5 & 50 & $\mathrm{Nt}$ & $\mathrm{Nt}$ & $\mathrm{Nt}$ \\
\hline & Methanol & 12.5 & $\mathrm{Nt}$ & $\mathrm{Nt}$ & $\mathrm{Nt}$ & $\mathrm{Nt}$ \\
\hline & Ethanol & 25 & $\mathrm{Nt}$ & $\mathrm{Nt}$ & $\mathrm{Nt}$ & $\mathrm{Nt}$ \\
\hline \multirow{4}{*}{ Emblica officinalis } & Acetone & 12.5 & 25 & 25 & 25 & 12.5 \\
\hline & Methanol & 12.5 & 50 & 25 & 25 & 25 \\
\hline & Ethanol & 25 & 50 & 50 & $\mathrm{Nt}$ & 50 \\
\hline & Cold aqueous & 50 & $\mathrm{Nt}$ & $\mathrm{Nt}$ & $\mathrm{Nt}$ & $\mathrm{Nt}$ \\
\hline \multirow{5}{*}{ Mentha arvensis } & Acetone & 6.25 & 25 & $\mathrm{Nt}$ & 12.5 & 12.5 \\
\hline & Methanol & 12.5 & 50 & $\mathrm{Nt}$ & 25 & 25 \\
\hline & Ethanol & 6.25 & 25 & $\mathrm{Nt}$ & 25 & 50 \\
\hline & Cold aqueous & 50 & $\mathrm{Nt}$ & $\mathrm{Nt}$ & $\mathrm{Nt}$ & $\mathrm{Nt}$ \\
\hline & Hot aqueous & 50 & $\mathrm{Nt}$ & $\mathrm{Nt}$ & $\mathrm{Nt}$ & $\mathrm{Nt}$ \\
\hline \multirow{5}{*}{ Rauvolfia serpentina } & Acetone & 25 & 12.5 & $\mathrm{Nt}$ & 25 & 25 \\
\hline & Methanol & 12.5 & 25 & $\mathrm{Nt}$ & 50 & $\mathrm{Nt}$ \\
\hline & Ethanol & 6.25 & 25 & $\mathrm{Nt}$ & $\mathrm{Nt}$ & $\mathrm{Nt}$ \\
\hline & Cold aqueous & 25 & 50 & $\mathrm{Nt}$ & $\mathrm{Nt}$ & $\mathrm{Nt}$ \\
\hline & Hot aqueous & 25 & $\mathrm{Nt}$ & $\mathrm{Nt}$ & $\mathrm{Nt}$ & $\mathrm{Nt}$ \\
\hline \multirow{4}{*}{ Terminalia arjuna } & Acetone & 25 & 25 & 25 & 25 & 25 \\
\hline & Methanol & 12.5 & 12.5 & 50 & 12.5 & 12.5 \\
\hline & Ethanol & 12.5 & 25 & 25 & 12.5 & 50 \\
\hline & Cold aqueous & 25 & 50 & 50 & $\mathrm{Nt}$ & $\mathrm{Nt}$ \\
\hline \multirow{3}{*}{ Withania somnifera } & Acetone & 12.5 & 25 & $\mathrm{Nt}$ & 25 & 25 \\
\hline & Methanol & 50 & 50 & $\mathrm{Nt}$ & 12.5 & 12.5 \\
\hline & Ethanol & 50 & $\mathrm{Nt}$ & $\mathrm{Nt}$ & 12.5 & 12.5 \\
\hline \multirow{5}{*}{ Zingiber officinale } & Acetone & 12.5 & 25 & $\mathrm{Nt}$ & $\mathrm{Nt}$ & $\mathrm{Nt}$ \\
\hline & Methanol & 12.5 & 50 & $\mathrm{Nt}$ & $\mathrm{Nt}$ & $\mathrm{Nt}$ \\
\hline & Ethanol & 25 & $\mathrm{Nt}$ & $\mathrm{Nt}$ & $\mathrm{Nt}$ & $\mathrm{Nt}$ \\
\hline & Cold aqueous & 25 & $\mathrm{Nt}$ & $\mathrm{Nt}$ & $\mathrm{Nt}$ & $\mathrm{Nt}$ \\
\hline & Hot aqueous & $\mathrm{Nt}$ & $\mathrm{Nt}$ & $\mathrm{Nt}$ & $\mathrm{Nt}$ & $\mathrm{Nt}$ \\
\hline \multicolumn{2}{|c|}{ Sodium benzoate } & 12.5 & 25 & 50 & 12.5 & 12.5 \\
\hline
\end{tabular}

Nt: not tested.

the organic extracts, alcoholic extracts displayed the best antimicrobial activity in comparison to acetonic extracts (Table 2), thus substituting the findings of earlier workers who rated methanol and ethanol as best solvent for the extraction of antimicrobial compounds from plants followed by acetone and water $[5,15,16,25]$. Several compounds, tannins, flavonoids, coumarins, thiosulfinates, glucosinolates, and saponins, isolated from these plants are secondary metabolites which are responsible for the antimicrobial and medicinal properties of plants $[2,3,8,17]$.

3.2. Sensitivity of Five Tested Microbes. B. cereus, Serratia, R. mucilaginosa, A. flavus, and P. citrinum revealed varying sensitivities to the 40 tested extracts (Table 2). With respect to $B$. cereus, thirty-four extracts showed inhibitory activity and 16 extracts had no activity. In case of Serratia, 25 extracts displayed inhibitory activity and 15 extracts showed no activity. $R$. mucilaginosa was the most resistant of the tested microorganisms. Nine extracts exhibited inhibitory activity and 31 extracts had no inhibitory activity. Seventeen extracts showed inhibitory activity against two moulds ( $A$. flavus and $P$. citrinum). Based on the inhibitory activity of plant extract, Gram-positive bacteria B. cereus demonstrated more sensitivity to the extracts than Gram-negative bacteria and fungi. The present findings are consistent with the results obtained by earlier workers who reported that plant extracts are more active against Gram-positive bacteria than against Gram-negative bacteria $[3,5,16,17,48,51-53]$. This is attributed to the differences in the outer layers of Gramnegative and Gram-positive bacteria. Gram-negative bacteria possess an outer membrane and a unique periplasmic space not found in Gram-positive bacteria $[5,54,55]$.

3.3. Determination of Minimum Inhibitory Concentration. The minimum inhibitory concentration was determined for 31 active plant extracts which show antimicrobial activity against microbes associated with juices (Table 3). The MIC of the 31 active plant extracts showed that MIC ranged between 
$3.12 \mathrm{mg} / \mathrm{mL}$ and $50 \mathrm{mg} / \mathrm{mL}$ for the organic extracts and between 25 and $50 \mathrm{mg} / \mathrm{mL}$ for the aqueous extracts. When comparing the MIC values of the tested plants, the ethanolic extract of $C$. asiatica appeared to be the most effective with the lowest inhibitory concentration being $3.15 \mathrm{mg} / \mathrm{mL}$ against $B$. cereus. Methanolic extracts of C. asiatica, $M$. arvensis, and $R$. serpentina were the second most effective plant extracts with MIC of $6.25 \mathrm{mg} / \mathrm{mL}$. Many plant extracts show MIC in the range of $25-50 \mathrm{mg} / \mathrm{mL}$ and were thus shown to be less effective against microbes isolated from juices. It has been established that MIC results do not always correlate well with the DIZ values but, in present investigation, the observation of MIC related with the DIZ value might be due to the adoption of disc diffusion assay for both antimicrobial activity and MIC determination of plant extracts [16]. Similar results of MIC of different plants in different solvents have been observed by several authors against different microbes $[3,5,9-13,16,56,57]$.

\section{Conclusion}

The results of present work established that all the tested plant extracts possess antimicrobial activity against selected microbes associated with juices. Alcoholic extracts of medicinal herbs such as $C$. asiatica, T. arjuna, and $R$. serpentina displayed better antimicrobial activity than chemical preservative sodium benzoate; therefore these plant extracts have the potential to extend the shelf life or they are used as natural preservatives in fruit juices.

\section{Conflict of Interests}

The authors declare that there is no conflict of interests regarding the publication of this paper.

\section{Acknowledgment}

The authors are thankful for Kurukshetra University, Kurukshetra, for the financial assistance.

\section{References}

[1] K. R. Aneja, R. Dhiman, N. K. Aggarwal, and A. Aneja, "Emerging preservation techniques for controlling spoilage and pathogenic microorganisms in fruit juices," International Journal of Microbiology, vol. 2014, Article ID 758942, 14 pages, 2014.

[2] M. M. Tajkarimi, S. A. Ibrahim, and D. O. Cliver, "Antimicrobial herb and spice compounds in food," Food Control, vol. 21, no. 9, pp. 1199-1218, 2010.

[3] R. Dhiman, N. K. Aggarwal, and M. Kaur, "Comparative evaluation of antimicrobial activities of commonly used indian spices against microbes associated with juices," Research Journal of Microbiology, vol. 10, no. 4, pp. 170-180, 2015.

[4] N. C. C. Silva and A. Fernandes Júnior, "Biological properties of medicinal plants: a review of their antimicrobial activity," The Journal of Venomous Animals and Toxins Including Tropical Diseases, vol. 16, no. 3, pp. 402-413, 2010.
[5] B. Shan, Y.-Z. Cai, J. D. Brooks, and H. Corke, "The in vitro antibacterial activity of dietary spice and medicinal herb extracts," International Journal of Food Microbiology, vol. 117, no. 1, pp. 112-119, 2007.

[6] D. S. Arora and J. Kaur, "Antimicrobial activity of spices," International Journal of Antimicrobial Agents, vol. 12, no. 3, pp. 257-262, 1999.

[7] P. K. Sofia, R. Prasad, V. K. Vijay, and A. K. Srivastava, "Evaluation of antibacterial activity of Indian spices against common foodborne pathogens," International Journal of Food Science and Technology, vol. 42, no. 8, pp. 910-915, 2007.

[8] M. M. Cowan, "Plant products as antimicrobial agents," Clinical Microbiology Reviews, vol. 12, no. 4, pp. 564-582, 1999.

[9] L. R. Beuchat, "Ecological factors influencing survival and growth of human pathogens on raw fruits and vegetables," Microbes and Infection, vol. 4, no. 4, pp. 413-423, 2002.

[10] M. Friedman, P. R. Henika, and R. E. Mandrell, "Bactericidal activities of plant essential oils and some of their isolated constituents against Campylobacter jejuni, Escherichia coli, Listeria monocytogenes, and Salmonella enterica," Journal of Food Protection, vol. 65, no. 10, pp. 1545-1560, 2002.

[11] M. Friedman, P. R. Henika, C. E. Levin, and R. E. Mandrell, "Antibacterial activities of plant essential oils and their components against Escherichia coli O157:H7 and Salmonella enterica in apple juice," Journal of Agricultural and Food Chemistry, vol. 52, no. 19, pp. 6042-6048, 2004.

[12] S. Burt, "Essential oils: their antibacterial properties and potential applications in foods: a review," International Journal of Food Microbiology, vol. 94, no. 3, pp. 223-253, 2004.

[13] J. Mosqueda-Melgar, R. M. Raybaudi-Massilia, and O. MartínBelloso, "Non-thermal pasteurization of fruit juices by combining high-intensity pulsed electric fields with natural antimicrobials," Innovative Food Science and Emerging Technologies, vol. 9, no. 3, pp. 328-340, 2008.

[14] R. M. Raybaudi-Massilia, J. Mosqueda-Melgar, R. SolivaFortuny, and O. Martín-Belloso, "Control of pathogenic and spoilage microorganisms in fresh-cut fruits and fruit juices by traditional and alternative natural antimicrobials," Comprehensive Reviews in Food Science and Food Safety, vol. 8, no. 3, pp. 157-180, 2009.

[15] J. A. J. Sunilson, R. Suraj, G. Rejitha, K. Anandarajagopal, A. V. A. G. Kumari, and P. Promwichit, "In vitro antimicrobial evaluation of Zingiber officinale, Curcuma longa and Alpinia galanga extracts as natural food preservatives," American Journal of Food Technology, vol. 4, no. 5, pp. 192-200, 2009.

[16] N. S. Weerakkody, N. Caffin, M. S. Turner, and G. A. Dykes, "In vitro antimicrobial activity of less-utilized spice and herb extracts against selected food-borne bacteria," Food Control, vol. 21, no. 10, pp. 1408-1414, 2010.

[17] P. S. Negi, "Plant extracts for the control of bacterial growth: efficacy, stability and safety issues for food application," International Journal of Food Microbiology, vol. 156, no. 1, pp. 7-17, 2012.

[18] A. K. Tyagi, D. Gottardi, A. Malik, and M. E. Guerzoni, "Antiyeast activity of mentha oil and vapours through in vitro and in vivo (real fruit juices) assays," Food Chemistry, vol. 137, no. 1-4, pp. 108-114, 2013.

[19] A. K. Tyagi, D. Gottardi, A. Malik, and M. E. Guerzoni, "Chemical composition, in vitro anti-yeast activity and fruit juice preservation potential of lemon grass oil," LWT_Food Science and Technology, vol. 57, no. 2, pp. 731-737, 2014. 
[20] D. Bukvicki, D. Gottardi, A. K. Tyagi et al., "Scapania nemorea liverwort extracts: investigation on volatile compounds, in vitro antimicrobial activity and control of Saccharomyces cerevisiae in fruit juice," LWT-Food Science and Technology, vol. 55, no. 2, pp. 452-458, 2014.

[21] A. Lucera, C. Costa, A. Conte, and M. A. Del Nobile, "Food applications of natural antimicrobial compounds," Frontiers in Microbiology, vol. 3, article 287, 2012.

[22] J. Mosqueda-Melgar, R. M. Raybaudi-Massilia, and O. Martin Belloso, "Microbiological shelf life and sensory evaluation of fruit juices treated by high intensity electric fields and antimicrobials," Food and Bioproducts Processing, vol. 10, pp. 123-142, 2012.

[23] K. A. Lawlor, J. D. Schuman, P. G. Simpson, and P. J. Taormina, "Microbiological spoilage of beverages," in Compendium of the Microbiological Spoilage of Foods and Beverages, W. H. Sperber and M. P. Doyle, Eds., Food Microbiology and Food Safety, Springer, New York, NY, USA, 2009.

[24] K. R. Aneja, R. Dhiman, N. K. Aggarwal, V. Kumar, and M. Kaur, "Microbes associated with freshly prepared juices of citrus and carrots," International Journal of Food Science, vol. 2014, Article ID 408085, 7 pages, 2014.

[25] C. Sharma, K. R. Aneja, R. Kasera, and R. Aneja, "Antimicrobial potential of Terminalia chebula Retz. Fruit extracts against ear pathogens," World Journal of Otorhinolaryngology, vol. 2, pp. 813, 2012.

[26] K. J. Gohil, J. A. Patel, and A. K. Gajjar, "Pharmacological review on Centella asiatica: a potential herbal cure-all," Indian Journal of Pharmaceutical Sciences, vol. 72, no. 5, pp. 546-556, 2010.

[27] B. Dora and J. Khatri, "Centella asiatica: elexier of life," International Journal of Research in Ayurveda and Pharmacy, vol. 2, no. 2, pp. 431-438, 2011.

[28] I. Chattopadhyay, K. Biswas, U. Bandyopadhyay, and R. K. Banerjee, "Turmeric and curcumin: biological actions and medicinal applications," Current Science, vol. 87, no. 1, pp. 44-53, 2004.

[29] K. R. Aneja, R. Joshi, and C. Sharma, "In vitro antimicrobial activity of Sapindus mukorossi and Emblica officinalis against dental caries pathogens," Ethnobotanical Leaflets, vol. 14, pp. 402-412, 2010.

[30] M. M. Kumbalwar, A. B. Ingle, and M. H. Shende, "Antimicrobial activity of Mentha arvensis (pudina) against on gram negative bacteria," Indian Journal of Applied Research, vol. 4, no. 4, pp. 488-489, 2011.

[31] M. B. Azmi and S. A. Qureshi, "Methanolic root extract of Rauwolfia serpentina benth improves the glycemic, antiatherogenic, and cardioprotective indices in alloxan-induced diabetic mice," Advances in Pharmacological Sciences, vol. 2012, Article ID 376429, 11 pages, 2012.

[32] K. R. Aneja, C. Sharma, and R. Joshi, "Antimicrobial activity of Terminalia arjuna Wight \& Arn: an ethnomedicinal plant against pathogens causing ear infection," Brazilian Journal of Otorhinolaryngology, vol. 78, no. 1, pp. 68-74, 2012.

[33] S. K. Verma and A. Kumar, "Therapeutic uses of Withania somnifera (ashwagandha) with a note on withanolides and its pharmacological actions," Asian Journal of Pharmaceutical and Clinical Research, vol. 4, no. 1, pp. 1-4, 2011.

[34] K. R. Aneja, R. Joshi, and C. Sharma, "Potency of Barleria prionitis L. bark extracts against oral diseases causing strains of bacteria and fungi of clinical origin," New York Science, vol. 3, pp. 5-12, 2010.
[35] S. R. Sridhar, R. V. Rajagopal, R. Rajavel, S. Masilamani, and S. Narasimhan, "Antifungal activity of some essential oils," Journal of Agricultural and Food Chemistry, vol. 51, no. 26, pp. 75967599, 2003.

[36] S. K. S. Al-Burtamani, M. O. Fatope, R. G. Marwah, A. K. Onifade, and S. H. Al-Saidi, "Chemical composition, antibacterial and antifungal activities of the essential oil of Haplophyllum tuberculatum from Oman," Journal of Ethnopharmacology, vol. 96, no. 1-2, pp. 107-112, 2005.

[37] T. K. Chattapadhyay and P. Dureja, "Antifungal activity of 4methyl-6-alkyl-2H-pyran-2-ones," Journal of Agricultural and Food Chemistry, vol. 54, no. 6, pp. 2129-2133, 2006.

[38] K. Das, R. K. S. Tiwari, and D. K. Shrivastava, “Techniques for evaluation of medicinal plant products as antimicrobial agent: current methods and future trends," Journal of Medicinal Plants Research, vol. 4, no. 2, pp. 104-111, 2010.

[39] K. A. Hammer, C. F. Carson, and T. V. Riley, "Antimicrobial activity of essential oils and other plant extracts," Journal of Applied Microbiology, vol. 86, no. 6, pp. 985-990, 1999.

[40] C. Thongson, P. M. Davidson, W. Mahakarnchanakul, and J. Weiss, "Antimicrobial activity of ultrasound-assisted solventextracted spices," Letters in Applied Microbiology, vol. 39, no. 5, pp. 401-406, 2004.

[41] I. Ahmad and A. Z. Beg, "Antimicrobial and phytochemical studies on 45 Indian medicinal plants against multi-drug resistant human pathogens," Journal of Ethnopharmacology, vol. 74, no. 2, pp. 113-123, 2001.

[42] B. K. Dash, H. M. Faruquee, S. K. Biswas, M. K. Alam, S. M. Sisir, and U. K. Prodhan, "Antibacterial and antifungal activities of several extracts of Centella asiatica L. against some human pathogenic microbes," Life Sciences and Medicine Research, vol. 2011, pp. 1-5, 2011.

[43] T. Arumugam, M. Ayyanar, Y. J. Koil Pillai, and T. Sekar, "Phytochemical screening and antibacterial activity of leaf and callus extracts of Centella asiatica," Bangladesh Journal of Pharmacology, vol. 6, no. 1, pp. 55-60, 2011.

[44] J. T. James and I. A. Dubery, "Pentacyclic triterpenoids from the medicinal herb, Centella asiatica (L.) urban," Molecules, vol. 14, no. 10, pp. 3922-3941, 2009.

[45] S. Dwivedi, "Terminalia arjuna Wight \& Arn.-A useful drug for cardiovascular disorders," Journal of Ethnopharmacology, vol. 114, no. 2, pp. 114-129, 2007.

[46] S. Jain, P. P. Yadav, V. Gill, N. Vasudeva, and N. Singla, "Terminalia arjuna a sacred medicinal plant: phytochemical and pharmacological profile," Phytochemistry Reviews, vol. 8, no. 2, pp. 491-502, 2009.

[47] S. Saeed and P. Tariq, "Antimicrobial activities of Emblica officinalis and Coriandrum sativum against gram positive bacteria and Candida albicans," Pakistan Journal of Botany, vol. 39, no. 3, pp. 913-917, 2007.

[48] B. Mahesh and S. Satish, "Antimicrobial activity of some important medicinal plant against plant and human pathogens," World Journal of Agricultural Sciences, vol. 4, pp. 839-843, 2008.

[49] S. Arora, S. Dhillon, G. Rani, and A. Nagpal, "The in vitro antibacterial/synergistic activities of Withania somnifera extracts," Fitoterapia, vol. 75, no. 3-4, pp. 385-388, 2004.

[50] A. Nostro, M. P. Germanò, V. D’Angelo, A. Marino, and M. A. Cannatelli, "Extraction methods and bioautography for evaluation of medicinal plant antimicrobial activity," Letters in Applied Microbiology, vol. 30, no. 5, pp. 379-384, 2000. 
[51] N. A. A. Ali, W.-D. Jülich, C. Kusnick, and U. Lindequist, "Screening of Yemeni medicinal plants for antibacterial and cytotoxic activities," Journal of Ethnopharmacology, vol. 74, no. 2, pp. 173-179, 2001.

[52] E. A. Palombo and S. J. Semple, "Antibacterial activity of traditional Australian medicinal plants," Journal of Ethnopharmacology, vol. 77, no. 2-3, pp. 151-157, 2001.

[53] R. Nair and S. Chanda, "Activity of some medicinal plants against certain pathogenic bacterial strains," Indian Journal of Pharmacology, vol. 38, no. 2, pp. 142-144, 2006.

[54] E. Ceylan and D. Y. C. Fung, "Antimicrobial activity of spices," Journal of Rapid Methods and Automation in Microbiology, vol. 12, no. 1, pp. 1-55, 2004.

[55] P. López, C. Sánchez, R. Batlle, and C. Nerín, "Solid- and vaporphase antimicrobial activities of six essential oils: susceptibility of selected foodborne bacterial and fungal strains," The Journal of Agricultural and Food Chemistry, vol. 53, no. 17, pp. 69396946, 2005.

[56] N. Kapoor, U. Narain, and K. Misra, "Bio-active conjugates of curcumin having ester, peptide, thiol and disulfide links," Journal of Scientific and Industrial Research, vol. 66, no. 8, pp. 647-650, 2007.

[57] K. S. Parvathy, P. S. Negi, and P. Srinivas, "Antioxidant, antimutagenic and antibacterial activities of curcumin- $\beta$-diglucoside," Food Chemistry, vol. 115, no. 1, pp. 265-271, 2009. 

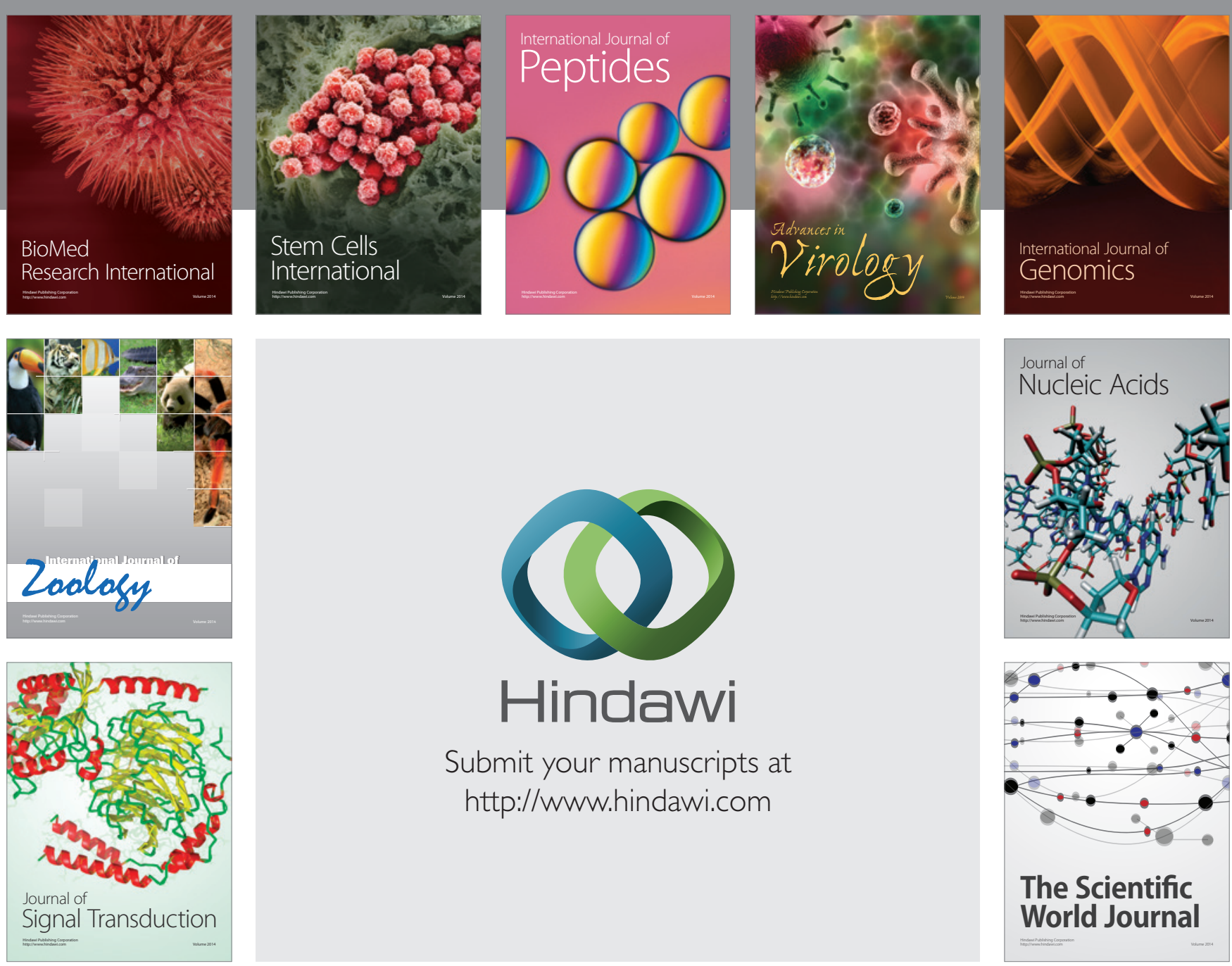

Submit your manuscripts at

http://www.hindawi.com
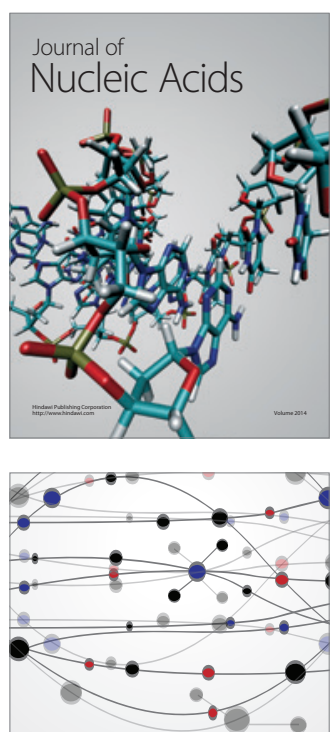

The Scientific World Journal
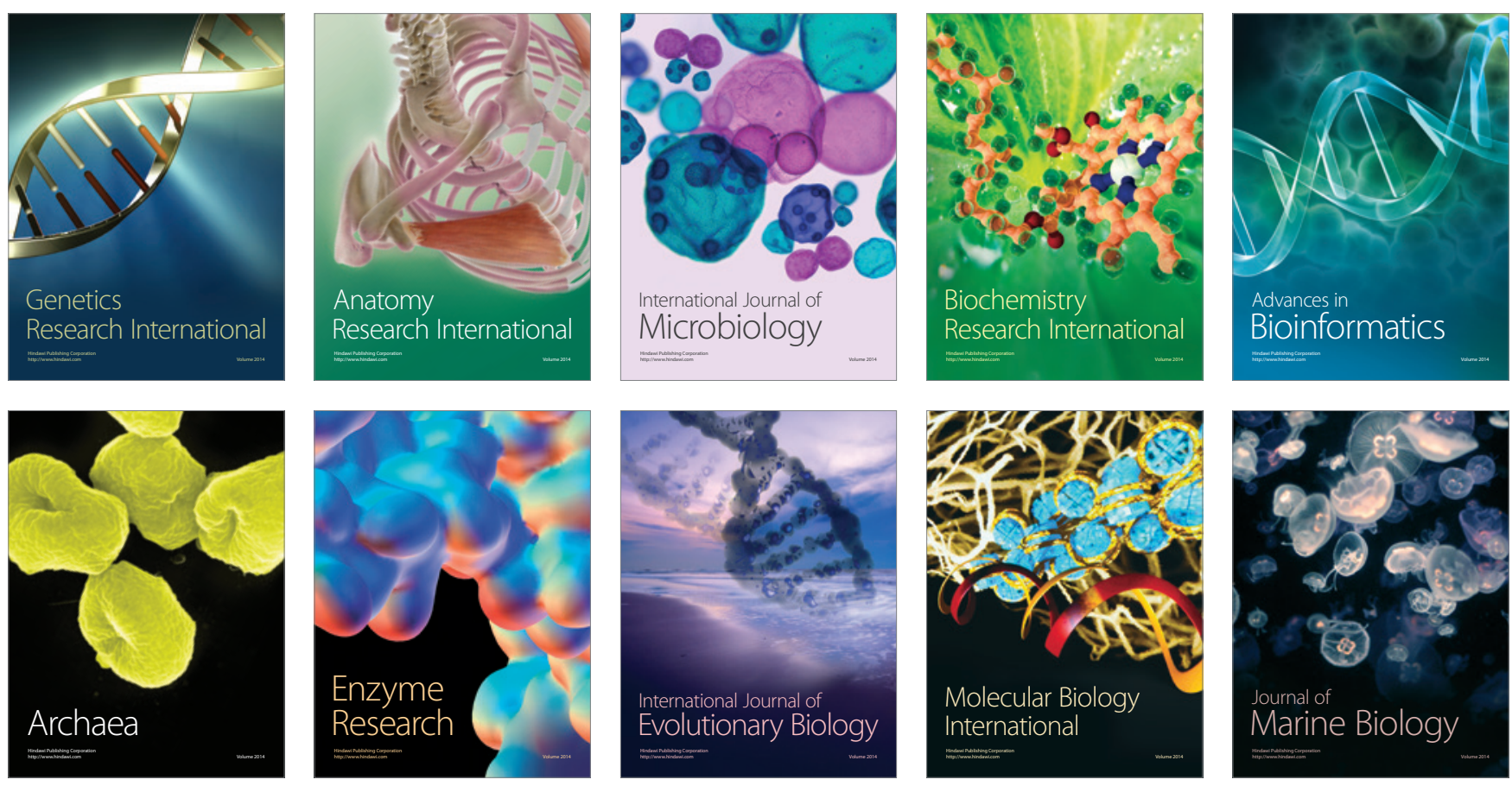